industrial areas which are menaced with post-war unemployment, and when this need has been met, the dispersal of industry and populations into communities ten or fifteen miles outside existing towns, as contemplated, for example, in the Plymouth plan. The provisions of the Act, as in all legislation dealing with the ownership of land, are complicated and difficult, but the Committee believes it offers a more acceptable solution of the problems incidental to the public acquisition of land than has been proposed in various plans put forward since planning seized the public imagination.

\section{Universities of Britain and the Future}

A sPECIAL number of the Political Quarterly devoted to the future of the universities of Britain contains an article by Sir Lawrence Bragg, "Organisation and Finance of Science in Universities". Sir Lawrence urges the importance of further steps to ensure that the fullest use is made of scientific men and potential scientific workers of the highest quality; and he suggests that more care should be taken to see that the highest ability does not 'fall off the educational ladder' before reaching the university, and that young people possessing such qualities should be earefully guided as to the courses they pursue at the university and the careers they take up afterwards. Then he suggests that an attempt should be made to avoid distracting our best university men from their real work by loading upon them too many extraneous duties, and finally he directs attention to the way in which lack of sufficient money for aids to research reduces the efficiency of our best scientific investiga. tors. Dr. C. P. Snow also examines the question of careers, and pleads for a standing Government committee to report at least once a year on trends in employment of graduates; the Appointments Department of the Ministry of Labour should act in close touch with such a standing committee and have as an essential task the diffusion of information to undergraduates; and the university appointments boards should be strengthened in the large universities on the Cambridge scale, and developed on tutorial lines in the smaller universities. Sir Ernest Simon discusses the number of university students, and Mr. G. D. H. Cole's article on "The Social Studies in the Universities" includes a suggestion for group research in place of individual research for the average postgraduate student, which may have potentialities elsewhere also. Bruce Truscot discusses the "University and its Region", indicating possible developments, and Prof. John Macmurray the functions of a university, stressing the importance of the cultural function, in which the universities of Great Britain are most conspicuously lacking.

\section{Research and Development in Scotland}

Some further notes on "Scientific Research in Scotland" are contributed by Mr. R. H. S. Robertson to Discovery of October, to some extent amplifying those in Bulletin No. 3 of the Scottish Reconstruction Committee (see Nature, August 12, p. 205). Some reference is made to the research stations already established in Scotland such as the Macaulay Institute, the Rowett Institute and the Fisheries Research Station at Torry, but no fresh evidence is advanced in favour of the formation of a new Scottish research station or branch of the Department of Scientific and Industrial Research. What is required is rather more attention to local conditions and problems and more effective liaison with the research boards and stations of the Department, whether they are located in Scotland or elsewhere. Modification or adaptation of the Portal house may be as important to suit conditions in Devon or Cornwall as to suit those in Scotland. To duplicate the work of the Building Research Station when the first need is a large allround expansion of research would be both wasteful and inefficient. The national research stations, wherever located, should be strengthened so as to be capable of dealing with the development of national resources, whether they are found in Cornwall or Durham, Glamorgan or Buchan. In regard to the location of industry, $\mathrm{Mr}$. Robertson is on firmer ground, and his paper emphasizes the need for action on the lines of the Barlow Report and as foreshadowed in the White Paper on "Employment Policy".

\section{Early Medical Books at Glasgow}

To illustrate a current series of lectures on "The Evolution of Social Medicine", by Dr. Douglas Guthrie, there have been placed on view in the Hunterian Library of the University of Glasgow some interesting works from the Hunterian and the Ferguson Collections, and from the library of the Royal Faculty of Physicians and Surgeons. Dr. William Hunter, eminent in London as an obstetrician and an anatomist, though not so famous as his younger brother John, bequeathed his library and museum to the University of Glasgow, where it forms a rich mine of learning. Besides his own magnificent atlas, "The Anatomy of the Gravid Uterus" (1774), the books selected from Hunter's library include some of the earliest works on midwifery. Among the medical classics in the exhibition are the first edition of the works of Hippocrates, printed in Greek by Aldus of Venice in 1526, and another Aldine work, Celsus' "De Medicina", the oldest medical document after Hippocrates, of which the 1528 edition is shown, the Elorentine edition of 1478 being still stored away for safety. From the Ferguson Collection come two of the finest works of Paracelsus, "Grosse Wundarztney", 1536, and "Paramirum" (1565), next to which may be seen David Laing's copy of one of the rarest of medical books, Michæel Scot's "Liber phisionomie" (1477). Herbal literature is represented by "De historia stirpium" (1540), by Leonard Fuchs, Nehemiah Grew's "Anatomy of Plants" (1682), with many beautiful drawings, and the magnificent "Curious Herbal" of Elizabeth Blackwell (1737). Another rare work is "An Account of the Foxglove" (1785), in which William Withering of Birmingham, a friend of Erasmus Darwin, introduced the use of digitalis in heart disease, having learned of its use as a 'folk remedy' from his country patients. Al. though the valuable University manuscripts have been stored away for safety, it has been possible to show from the Faculty library a volume of letters of advice, or "consilia", written and signed by Herman Boerhaave of Leyden (1668-1738); the earliest minute book of Glasgow Medical Society (1815), and a manuscript diary of the Crimean War, written by George Buchanan, the first professor of clinical surgery at the University of Glasgow. The exhibition, which has been arranged with the co-operation of Dr. W. R. Cunningham, University librarian, and Dr. Snodgrass, librarian of the Royal Faculty of Physicians and Surgeons, will remain open until the end of January. 